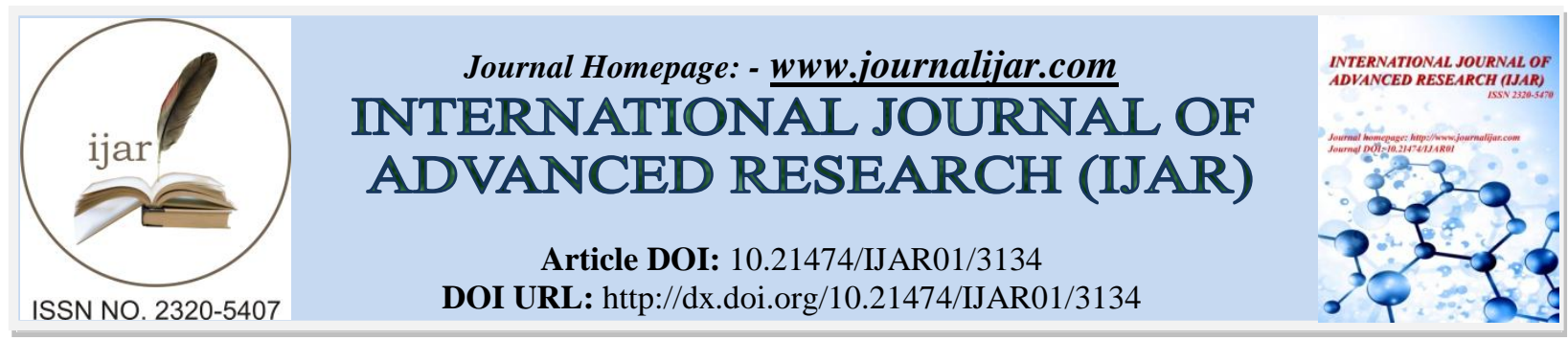

RESEARCH ARTICLE

\title{
COMMUNICATION AND AUDIOVISUAL: UNDERSTANDING THE METAPORE.
}

Vanessa Matos Dos Santos.

Universidade Federal de Uberlandia (UFU), Universidade de Sao Paulo (USP)- Brasil.

\section{Manuscript Info}

Manuscript History

Received: 13 December 2016

Final Accepted: 15 January 2017

Published: February 2017

Key words:-

Audiovisual, Education,

New Theory of Communication,

Metapore.

\begin{abstract}
The development of communication and information technology has resulted in a new spatiotemporal perception that determines new social, political and economic dynamics. The press has been part of this scenario as a boost for an ideal education. According to this logic, audiovisual can be comprehended way beyond daily limits, being more than just educative. This article shows the possibilities of this new horizon for an audiovisual educational understanding assuming that every audiovisual can be educative and more than that, these materials enable the invididual the freedom to feel, think and incite new understandings adding teacher's and screenwriter's understandings. In a way to develop this logic, the article shows the relation between audiovisual and education seeing that the sensitive provides a new way of communication. Lastly, the metapore that is different from the classical method is showed as a way to comprehend audiovisual respecting the dynamics of these phenomena and how they work and develop all around the world.
\end{abstract}

Copy Right, IJAR, 2017,. All rights reserved.

\section{Introduction:-}

Audiovisual has been used as a way of providing an approaching feeling among the subjects involved in the teaching-learning process as well as facilitates the dissemination of concepts and simulations of several experiences and moreover, audiovisual allows different ways of thoughts as a communicative message through different forms. Audiovisual allows to imagine different ways of communicational message appropriation through different meanings and such potential has been even more intense in several contexts. The idea of an audiovisual education as a produced and used material to teach even if they have been used for noble purposes but they have been underutilized. This article shows that any audiovisual can be educative overcoming the assumed antagonism created between audiovisual education and non-audiovisual education.

This focus presupposes to comprehend that such assumption is connected with the ocidental thought that rationalized the world and established dubious relations in order to comprehend the knowledge as a division between idea and fact, subject and object, soul and body. Trying to direct the eyes of an individual that was labeled as educative shows the first way to deny all the potential of these materials. These materials show their textures, folds, cracks as they are. From a phenomenological perspective that explanation means label and fit them in categories created by us (artificial act) and therefore, out of the object. Instead of this it is need to describe the phenomenon. Describe in this case means "approach the men perspective that they experience as well as the way it is showed to the conscience" (Carmo, 2004:22). It is needed to feel and be the perspective. Merleau-Ponty says that to have knowledge an individual must be sensitive, linking the subject and the object. It is needed to value the 
unconscious. Everything that existed as knowledge in our conscious passed through our perception first. The feeling does not follow the rules of the individual so unconscious acts predominate above the conscious. Before reflecting about everything it is good to realize, to think. First feel then open to the world. The thought is always before the lived experience and to feel it is necessary to ignore the rules, the preestablished scripts. Audiovisual presents the potential to reach and awake sensitivity and this way helps in the hard work of letting loose from senses externally preestablished. This happens because audiovisual as an art represents a way of freedom of looking and meaning and the individual can feel and know not because it is external from the other but because it is actually the other and it not possible to distinguish between psych and visible. In this perspective this approaching occurs through communication. Communication is much bigger than this, devoid of materiality. It is something that establishes with the alterity principle. According to this and implying that Communication - as science - reaches what Marcondes Filho (2011) calls majority, a specific space of communication and it is needed to admit that communication is only possible by achieving a fact that is featured through a break paradoxically able to introduce life in a relation because it implies a radical change in what it was and what becomes after this break.

The facts are unique and imply in natural situations that enable real freedom of movement. The construction of an audiovisual narrative in a metapore communication reflects in dynamic facts without previous scripts, only following the natural flow. From this perspective, audiovisual ends up being underutilized and educative methods did not have a value in favor of a wider and emancipatory education. This article shows the useful use of audiovisual under the perspective of communication as a break (Marcondes Filho, 2010).

\section{Audiovisual and Education:-}

The wide potential of means of communication was too early recognized and used for several purposes from manipulative and persuasive advertising to direct target as education. This acknowledgment became more evident at first with the radio, then cinema and telecommunication consecrated the power of influence and persuasion of theses means. In the beginning of the 20th Century, after the invention of cinema the movies started being used pedagogically in schools. From this moment, many researches started being developed to verify the pedagogical potential in movies that besides offering a new way to see the world also enabled new ways of learning (Wittich; Shuller, 1979).

As the time goes, it was clear that the problem was not in the materials, but in its educational context use. Two sides ended up appearing related to the participation of audio visual in teaching-learning process. The American side disseminated an intuitive conception, seeing that the main exponents, Wittich and Schuller, defended a sensorial feeling as a learning method and in this case standed out only the teacher. Audio visual materials need to be comprehended by the teacher (being teacher's resources but not necessarily students' resources). It is possible to research from Kieffer and Cochran (1962) because of their guides of audio visual techniques. Audio visual could be efficiently used if they were resignified by the teachers. The french side had in Robert Lefranc (1980) its main diffuser. In many aspects the French side was better than the American side, mainly by its self image study and its meaning methods. This tradition becomes evident when during a long time the Image Theory studies were focused on Roland Barthes' studies but this work did not overcome that the messages should be decoded by the teachers inside the classroom and a few space is allowed for the students. It is important to highlight Dieuzeide (1965) that put the teacher as a moderator allowing certain space for the apprentice.

Until then, being French or American side, the researchers comprehended that the messages were an abstraction process derived from sensation and perception. The audiovisual experts had this understanding about the image and received a lot of criticism. The image is not a copy - less precise - of the reality. This conception was getting even more clear as long as the means of communication were developing and the researchers overcame the passive recipient idea. The media messages started being a part of the students and demanded more studies about it. Audiovisual could be efficiently used in classrooms and the focus turned in the way or the mechanisms that make the learning possible through media messages.

In Brazil, the dynamic use of audiovisual as educative purposes were not different. According to Franco (2010), image projections with movement have already arrived in 1896. The integration between cinema and education were already in movement and it was needed a renovation in education, for example the "New School Movement" consolidated by the pioneers. In this context, this integration was seen as an important boost for the development and progress in Brazil. These movements wanted a fair and egalitarian for men and women and ended up creating 
the National Institute of Educative Cinema (INCE) ${ }^{1}$ in 1937. The INCE activities wered closed in 1990 after several changes and initiatives that did not value the art and the culture.

The use of audiovisual in classroom (brazilian context) was marked by the repetition logic and not necessarily by the potential of esthetic appropriation that these materials could offer. Audiovisual and the cinema were even more adapting as tools (technical sense) by the teacher and the students were supposed to learn the content showed. Trained teachers using these means of communication in classroom started being incentivated by many governmental, federal and municipal programs from the '90s when the internet enabled new social, cultural and economic dynamics. An esthetic appropriation continued being ignored to give place to a guided media insertion that Franco (2013) describes as a repetitive/accumulative paradigm. The context of contemporary societies imply changes in the way of learning and appropriation. According to the author, it does not exist a necessity of collecting knowledge and the current scenario (marked by connectivity) demands new habilities on selecting/articulating paradigms. This means to know how to search and select contents.

The Brazilian context exposed until here allows to comprehend the reasons that made audiovisual creativity in classroom be gone. The proposal of this use of language and its technological support had already followed by manuals that showed themes, running time, equipments and theses rules blocked the cinematic creativity and turned out blockers and boring educative movies (Franco, 1988:46). The compreension and the respect about the affective and sensorimotor (cinematic language) to associate with education themes were constantly ignored to give place to proposals that guided monological repetition of contents. Audiovisual in this case was just the support for the conservatism in classrooms. The intuitive particularities of the audiovisual language that would allow new appropriations and perceptions were summarily ignored. There may be added the early prejudice of many teachers that used these materials in educative contexts and did not exist public policy that incentivated the teachers to use these materials and only with them it would be possible to associate cinema and education.

Changing the discussion to the production of audiovisual it is possible to verify that mainly because of new technologies and high use of connectivity in Brazil that it has been led to an even more collaborative context. The emergency of new formats and contents not always contemplated with a good esthetic quality but with high access for example homemade videos on Youtube shows that there is a big curiosity to know what other people produce and because of that there are many websites that allow the users to upload their own content be them personal, educative or professional blogs.

It is interesting to learn the certain point where audiovisual communicates something. The exposed material above corroborates the idea that the biggest challenge of these produced materials is to find a way to rethink and comprehend this communicative phenomenon Buttons that respond to stimuli are daily classified as "interactive", as though the single fact of signaling an action coincided with the complex process that entails the communication, therefore signal is not communication (Marcondes Filho, 2010).

\section{Thinking about a new theory of communication:-}

Communication is much bigger than this, devoid of materiality. It is something that establishes with the alterity principle. According to this and implying that Communication - as science - reaches what Marcondes Filho (2011) calls majority, a specific space of communication and it is needed to admit that communication is only possible by achieving a fact that is featured through a break paradoxically able to introduce life because it implies a radical change in what it was and what becomes after this break. The facts are unique and imply in natural situations that enable real freedom of movement.

The construction of an audiovisual narrative in a metapore communication reflects in dynamic facts without previous scripts. This dynamic was expressed in Chronique d'un été ${ }^{2}$ when Edgar Morin and Jean Rouch developed that showed a single question for different people. The answers and discussions were based on a metapore view. In

\footnotetext{
1 "About the legacy left by the INCE, Franco (2010:14) says:" Unlike many renewing initiatives that last a few and close without traces, the INCE left a production of more than 500 movies about several themes and different formats with so many genius creations by Humberto Mauro and uncountable productions from other filmmakers".

${ }^{2}$ Chronique d'un été (1960) documentar fulfilled in Paris by Edgard Morin and Jean Rouch and became a reference to what it is called "true cinema".
} 
this way, this logic entails a new scientific dynamic research polarized betwen objectivity and subjectivity, transmission and reception, signification and meaning (Marcondes Filho, 2010). Assuming this perspective implies to understand that communication occurs in a logical search to reach the sensible, the unique, the irreproducible of each experience.

In educative situations, audiovisual is usually useful to stimulate the learning and potentiate the communicational process. However, communication can be too far. The constant search for the "ideal format" created a situation that does not privilege the execution of effective communicational proposals but it privileges theories connected to technical progress. A lot of money has been spent in audacious technological projects that has not been influencing the reality of the people. There are a lot of materials that cannot even reach pedagogical objectives proposed because they ignore the basic meaning. It is needed to consider that there is an intangible point in the comprehension of this problem because it is important to identify the sensible and culminates in the necessity of causing a break. It is needed to touch and influence the individual in their cognitive-affective structure to establish a genuine communication and the conception of communication assumed by Marcondes Filho (2010) that when invoking the emitter/receiver the first is able to transmit signals that is going to be called communication from the receiver's point of view.

A movie or an educative audiovisual movie can communicate something if it destabilizes the people and forcing them to reflect. In this way, besides allowing a renewing esthetic experience also enables the alterity exercise and its reorganization. Assuming this perspective presupposes that communication cannot be massified from a single and ample meaning and this meaning is related to a semiotic conception. It is discussed the meaning that link together with the communicational fact and this fact is unique and no human can transfer it because only the individual that experiences the communication is able to know the provoking amplitude that this act has caused.

\section{Metapore and communication research:-}

Unlike the classical or traditional research, the research that assumes the communication as a fact that shows the necessity of rewriting the ways and revisits the themes as a function of a new context but especially as a function of the moment. Communication passes through this moment so the idea of preestablished methods and constantly applied do not fit in the perspective of audiovisual comprehension. This thought becomes more evident when it is possible to comprehend Marcondes Filho's saying (2008:151-152) that communication must be felt, experienced and it is needed to participate to investigate it and this communication is history, sociology, anthropology therefore, something dead.

The "live" is precisely in the absence of a fixed, final, closed and aseptic method. The researcher needs to find ways of looking and studying the object. The comprehension of this object is in a context and how many times it is observed the same object, how many times it is needed to rebuild and rediscover distint ways of observing. The mind must be open to the constant movements of the world and such movements are unique, irreproducible and likely of perceptions that are unique as well. In this logic, more than the reception of these contents by touchable means (typical vision of empirism) it is important to highlight the perception of the meaning defended by MerleauPonty and the perception is not a cold representation but still an existence fact with body characteristics. This perception is seen when the individual looks at the object and feels and becomes part of this object and the body notices the perception of the movement and the immobility keeps it confused, stunted, stuck (MERLEAU-PONTY, 1994).

When a person looks at the object it is showed that the person wishes this object and the sensations are linked to movements and every object influences the realization of a gesture. It is not a representatio but a creation, new possibilities of interpretation (Nóbrega, 2008:142). The work of art it is the local that enables a space for more intense perceptual perspectives and it is important to realize the visible and invisible notion. According to the philoshopher the unoccupied spaces are important, seeing that they are part of the whole context and they are able to accelerate the curiosity.

To Merleau-Ponty, the objects, the things only exist when the individual notices it and the perception cannot be conceived according to Science. The perception is felt and there are no previous methods established, there is not a rule to be followed. The person notices and feels the way they want it therefore audiovisual will only exist if the person perceives it and this perception is only possible by seeing the sensible. To Merleau-Ponty there is no way to 
observe the phenomenon from the outsite and the perception is only seen as long as the individual becomes a part of this object and when is not possible to separate them. The audiovisual has the ability to reach deeper layers and enables other ways of learning. The perception is unique and inalienable and it is possible to realize that every human beeing is able to conquer it by freedom of spirit.

Watching these movements presuppose to comprehend the communication as a break that leads to a qualitative boost. Audiovisual can be noticed when it is possible to communicate something, when you can touch the person and the researcher needs to comprehend and not to apprehend. Not everything can be comprehended because of the subjectivity. It is clear that the classical method conception does not offer mechanisms of apprehension, While the metapore imprisons, the metapore releases the researcher to feel and capture the fact. The metapore's researcher needs to get rid of a preestablished thought and be open to observe new movements, assuming the role of a world spectator (Dantas, 2012). This spectator is the world and it is surrounded by lines, vectors and unique sensations in unique situations. The body in this case needs to be open, unfinished to have conditions to be able to receive and allows new thoughts (MERLEAU-PONTY, 1994). This relation builds the object and not the contrary. The base is the communicational fact and can be comprehended by new characteristics and by ephemerality, movement and unpredictability.

If the meaning of metapore enables researches that were impossible without this view on the other hand imposes challenges from an uncontrolled object. "The object is neither known nor conceptualized; it does not remain for a long time; it is not stuck, parked or frozen; it does not show when it is going to happen again"(Marcondes Filho, 2008:1). Even so there are ways of operating the metapore, a terminology utilized to replace the method that entails a determined way that must be followed. The metapore functions by a space, passage that allows a communicational fact. The researcher does not focus on learning, capturing or dissecting but on experiencing and feeling it. The researcher does not have a specific method but operational formats that in essence guide the path of the researcher through the object. Their search is not the meaning but the sense that is only awake before a communicational break. The event that is the essential condition so that this occurs does not have a sense but it is felt when studying the event regardless of the duration. The researcher must accept this phenomenon (devoid methodological bonds). The sensibility, looking and opening to think are essential to go through a metapore's research and this researcher needs to have a great ability to describe and report the events. The language in this case can be an obstacle once not everything it is experienced can be expressed in words, texts, etc.

It is needed to be open to an instanteneous apprehension. This necessity resets the importance of intellectual intuition or "events that preced and succeed the sensitive intuition" (Marcondes Filho, 2010:254). It is up to the temporality of the metapore defined by the author as an "extended temporality marked by peaks of bliss". These peaks correspond to sensitive intuition and the turning moment, the moment of the occurence of this phenomenon that justifies the statement of a genuine communication that enables the break and the impression of something that marks, forces, shocks and breaks the individual.

This transformation that shocks, forces can happen in the first moments of the event (like a strong emotion or even at the movies) and the effects will be felt in previous moments. In this case, the intellectual intuition processes afterwards, in a way that remains resonating in the subject and transforming after a movie for example. But in educative situations the meaning is different, because "the informations are exposed creating a intellectual intuition until a sensitive intuition that creates the sense, therefore the intuitive peak occurs in the end when the changes are expressed through persistence and continuity of the elements" (Dantas, 2012, p.12).

Audiovisual has the potential of enabling peaks of bliss in the beginning (while a movie) and in the end (while educative process). It is important and needed to investigate under a new view that allows to comprehend as more than just technical elements of teaching. Furthermore it is about an enlightenment and point of resistence to break the cold logic of production and broadcasting of these materials. In the 80s, Franco (1988) had already expressed how boring was the educative audiovisual and maybe this is the possibility of learning what establishes communication in these expensive materials, enabling another ways of noticing and effectively feel them in all 


\section{Final considerations:-}

The investigation of the metapore consists in feeling, experiencing and recording. It is needed to let the sensible intuition touchs the person and this marks the event so that there is an opening that allows the researcher to record elements that were ignored by the strict methodological logic.

For not having fixed steps, the different does not need (and must not) be ignored. On the contrary, it helps to understand the phenomenon. Study procedures of communicative events must halt the examination of its own occurrence. It does not exist a goal oriented to be achieved or path to be taken. Conceive the reason investigation through metapore and free the researcher to exercise the look and redemption of his own subjectivity. Knowledge is always temporary and the route is eternal. The land is flat, characterized by unique gathering of wires, lines and vectors into a single point of the existence of human beings. For this reason, unlike what proclaimed the classical theories, the communication is not something that can be transferred, shared and communed by everybody. There must be a specific moment of opening between them. That particular time cannot be frozen and it is possible to feel the other, grasp the ungraspable and overcoming the logic of the material body to achieve a deeper climax, eclipsing in the immaterial. The purpose of the identification of the event is not grasp or understand. It is to experience something radically new that is capable of providing qualitative leaps in the relationship, allowing to identify and describe an event which is possible to see and observe in a single occurrence.

During many years the potential of audiovisual (the cinema for excellence) for education was considered a hostage of educative appellation. This designation was(and in many countries are) connected to a produced material with specific purposes and followed by a manual or pedagogical strategies. This formatted and antiquated conception reveals proposals that confine you instead of releasing the human creativity.

It is important to highlight that in the Brazilian context Franco has been developing for 40 years the conception that any audiovisual can be educative independent of the formatted ideia that was previously thought and closed. The educative aspect is in the unique relation that is established in the exhibition of the audiovisual corroborating with the ideia that "what is educative is not a movie, the cinema. Educative is the moment of the connection between the movie and the spectator and the result of this interaction is going to depend on the condition, the psychological and emotional moment of this spectator" (Franco, 2013). While watching, the individual suffers transformations and this is educative and it does not matter how many times this movie will be watched because the work is always new, "the soul of a man and the society are revisited and reinterpreted in every exhibition" (Franco, 2013).

In this sense, audiovisual provides a discovery of the subject itself, a move that could culminate in a communicational event that entails a qualitative leap from the point of view to communicational education. Regarding to the research involving educational audiovisual, the proposed metapore enables an opening never before displayed: the researcher can be sensitive and understand the phenomenon, beeing the communication event during an exhibition or even during the production of an educative material. The transformation occurs to the producer and the the spectator of these materials as well so it is not a cold production or even chronologically dated seeing that "the great and eternal cinematographic work regardless of beeing older or futuristic films they have a philosophical tone because they make an individual stimulus to think and understand the past and the future "(Franco, 2013). Therefore, the author's statement establishes a direct connection with the ultimate goal of education that is to enable the men, clarifying the understanding of the past and future, envisioning and experiencing the freedom. 


\section{References:-}

1. CARMO, Paulo Sérgio (2004). Merleau-Ponty: uma introdução. São Paulo: EDUC.

2. DANTAS, Elenildes (2012). Apresentando o Metáporo, o meio de estudar a comunicação como Acontecimento. Anais do X Congresso da LUSOCOM - Comunicação, Cultura e Desenvolvimento. Lisboa, Portugal.

3. DIEUZEIDE, Henri (1965). Les Techniques audio-visuelles dans l'Enseignement, col. Nouvelle Encyclopédie Pédagogique, Paris, Presses Universitaires de France.

4. FRANCO, Marília (2013). O cinema jamais foi mero entretenimento [jul. 2013]. Entrevistador: Marcus Tavares. Ouro Preto-MG. Disponível em: http://www.revistapontocom.org.br/entrevistas/o-cinema-jamais-foie-ou-sera-mero-entretenimento Acesso em 2 setembro de 2013.

5. FRANCO, Marilia (2010). Hipótese-cinema: múltiplos olhares. In: Revista Contemporânea de Educação Faculdade de Educação da Universidade Federal do Rio de Janeiro. RJ., v.5, n.9. janeiro/julho 2010.

6. FRANCO, Marília (1997). Linguagens audiovisuais e cidadania. Comunicação \& Educação, São Paulo, (91: 32 a 35, maio/ago).

7. FRANCO, Marília (1989). Cinema e educação. In: Imagem/Tecnologia/Educação, nº 1, ago/out de 1989, p. 469.

8. KIEFFER, R. E.; COCHRAN, L. W (1962). Manual of audio-visual techniques. Prentice-Hall.

9. LEFRANC, Robert (1980). Las técnicas audiovisuales al servicio de la enseñanza. Buenos Aires: El Ateneo.

10. MARCONDES FILHO, Ciro (2008). Para entender a comunicação: contatos antecipados com a nova teoria. São Paulo: Paulus.

11. MARCONDES FILHO, Ciro (2010). Princípio da razão durante, vol.III, tomo 5, "O conceito de comunicação e a epistemologia metapórica" .São Paulo, Paulus.

12. MERLEAU-PONTY, Maurice (1999). Fenomenologia da percepção. São Paulo: Martins Fontes.

13. MORIN, Edgar; ROUCH, Jean (1961). Crônica de um verão. (filme / obra cinematográfica).

14. NÓBREGA, Terezinha Petrucia (2008). Corpo, percepção e conhecimento em Merleau-Ponty. Estudos de Psicologia, 13(2), 141-148.

15. WITTICH, Walter A.; SCHULLER, Charles F. (1979). Instructional technology: its nature and use. $6^{\mathrm{a}}$ ed. Harper \& Row Publishers. 